\title{
Immediate loading of mandibular single implant by using surgical guide and modeless digital prosthesis: a case report
}

\author{
Hyun-jeong Lim, Myung-Joo Kim, Ho-Beom Kwon, Young-Jun Lim* \\ Department of Prosthodontics, School of Dentistry, Seoul National University, Seoul, Republic of Korea
}

In this case report, immediate loading of an implant-supported single-tooth prosthesis through complete digital workflow. A patient presented for restoration of missing a single tooth in the mandibular first molar. The digital impression was made with intraoral scanner and implant was placed using surgical guide pre-fabricated with pre-operative computed tomography (CT) and scan data. After 1 week later, prefabricated customized abutment and provisional restoration were connected for immediate loading. After 8 weeks later, abutment level impression was taken by intraoral scanner. At 3 months later from implant installation, monolithic zirconia crown were fabricated. This clinical report presents satisfying result in accuracy and patient satisfaction. A completely modeless digital procedure met expectations regarding precision, esthetics, and functionality. (J Dent Rehabil Appl Sci 2017;33(4):299-306)

Key words: digital impression; surgical guide; CAD/CAM; immediate loading; intraoral scanner

\begin{abstract}
서론
임플란트 술식은 예지성 있는 성공적 보철 수복 치료 양식이 되었다. ${ }^{1}$ 오랜 기간 동안 전통적으로 임플란트 식 립은 이용 가능한 잔존골이 있어야 식립하는 술식이었다 고 할 수 있다. 그러나 임상에서 종종, 이렇게 잔존골에 의지해 식립된 임플란트는 불량한 식립 방향으로 심미성 이 저하되고 임플란트에 불리한 측방력이 발생하는 등의 여러 생역학적 문제를 가지게 되었고 보철 수복이 불가 능한 경우도 발생하기도 한다. 적절한 위치에 잘 식립된 임플란트는 대합치와 적절한 교합을 이루게 되고, 환자 스스로의 적절한 위생 관리가 가능하게 된다. 따라서 임 플란트 식립을 위한 수술보다 먼저 추후 수복할 보철적 결과를 고려하게 하는 새로운 개념이 등장하게 되었다. ${ }^{2,3}$ 보철적으로 계획된 위치에 유도된(guided) 임플란트 식 립을 위해, 초기 임상가들은 상실된 부위의 치아를 대체
\end{abstract}

*Correspondence to: Young-Jun Lim

Professor, Department of Prosthodontics, School of Dentistry, Seoul National University, 101 Daehak-ro, Jongno-gu, Seoul, 03080, Republic of Korea Tel: +82-2-2072-3816, Fax: +82-2-2072-3860, E-mail: limdds@snu.ac.kr Received: September 5, 2017/Last Revision: September 20, 2017/Accepted: September 21, 2017
할 보철물을 미리 왁스업하고 수술용 템플릿(surgical template)을 진단모형 상에서 제작하여 수술에 사용하 였다. 하지만 진단 모형의 단단한 표면은 구강 내 연조직 을 구현하지 못하며, 동일하지 않은 상황에서 제작된 수 술용 템플릿은 여러 단점이 있었으며, 진단 모형만으로 는 하방에 위치한 정확한 해부학적 구조물을 고려할 수 가 없다. ${ }^{3,4}$ 이런 단점들을 극복할 수 있는 방안으로 컴퓨 터 보조 수술(computer-assisted surgery, CAS)은 보철적 요인과 해부학적 요인 모두에 대해 최적의 삼차원적 임 플란트 위치를 결정할 수 있게 해준다. 이러한 CAS의 도 입은 저선량 CT, 3차원 임플란트 수술 계획 소프트웨어 그리고 오늘날 CAD/CAM 발전으로 인해 가능해졌다. ${ }^{5}$ CAS 이용시의 수술 전 컴퓨터 프로그램 상에서 해부학 적 구조물과 치조골의 삼차원적인 정보를 이용하여 중요 해부학적 구조물의 침범에 대해 미리 대비할 수 있어 구 체적이고 정확한 치료 계획을 할 수 있다. 술자에게 자신

CopyrightC 2017 The Korean Academy of Stomatognathic Function and Occlusion. (c) It is identical to Creative Commons Non-Commercial License. 
감을 주며 술자와 환자 모두에게 심리적 안정감을 주는 데도 기여한다. 또 다른 장점으로는 판막을 거상하지 않 는 시술이 가능하며 무절개(flapless) 시술이 통계적으로 유의하게 낮은 통증을 나타낸다고 하였다. ${ }^{6}$

최근 임플란트 시술 과정에 CT, 구강 스캐너 및 $\mathrm{CAD} /$ $\mathrm{CAM}$ 기술의 눈부신 발전으로 보다 정확한 수술 전 계획 이 가능하게 되었다. 또한, 인상재를 이용한 전통적인 인 상채득 방식이 아닌, 구강 스캐너를 이용하여 얻어진 구 강 내 정보를 통해 CT 데이터와 병합하여 정확한 수술용 가이드 제작이 가능하게 되었다. 이러한 모형 없이 제작 하는 디지털 보철 개념의 이러한 보철 수복 과정을 통해 미리 제작한 맞춤형 지대주 및 임플란트 보철물은 계획 된 위치에 식립 된 임플란트에 장착하여 술 후 즉시하중 이 가능하게 하며, 술 후 출혈이나 환자의 불편감, 술자의 번거로움을 덜어 줄 수 있다.

본 증례에서는 하악 대구치 단일 치아 상실 부위 수복 을 위해 구강 디지털 스캔 및 CT 데이터를 통해 정확한 수술 계획을 하고 미리 제작한 수술용 가이드를 이용한 임플란트 식립 후 술 전 미리 제작한 타이타늄 맞춤형 지 대주, 임시수복물로 술 후 즉시 하중을 부여한 뒤 지르코 니아 최종 수복물로 장착한 증례로 임상적으로 우수한 결과를 얻었기에 이를 보고하고자 한다.

\section{증례보고}

본 증례의 환자는 63세 남자환자로 하악 좌측 제1대구 치 치아 상실로 임플란트 수복을 원한다는 주소로 서울 대학교 치과병원에 내원하였다. 2년 전 \#36 치아 파절로 인해 발치 후 상실 상태로 지냈으며 임상적, 방사선학적 검사 시\#36 치아 상실로 인한 \#37 치아 근심 경사 및 전 반적인 치조골 소실과 구치부 치아 마모가 관찰되었으나
환자의 연령을 고려하였을 때 전반적으로 구강 위생관리 가 양호하였으며, 턱관절 이상이나 교합 장애 또한 관찰 되지 않았다.

임플란트 수술 및 보철 수복을 위한 계획을 위해 술 전 진단 및 준비과정을 진행하였다. 먼저, 진단을 위한 파노 라마(Fig. 1)와 치과용 CT를 촬영하였다. 수술용 가이드 제작을 위한 CT 촬영 사전 준비는 제작 회사의 메뉴얼 에 따라 진행하였다. 환자 진단을 위한 초진 시 예비 인상 채득 및 악간 관계 기록은 구강 스캐너 Trios3 (3Shape, Copenhagen, Denmark)를 사용하여 구내 디지털 인상 채득하였다. 치아 상실 부위인 하악 좌측 부위 대합치 부 위의 상악 반 악과 하악 그리고 악간 관계 기록을 위해 환자 교합상태에서 협측면을 스캔하는 디지털 인상 채 득 시행하였다(Fig. 2). 이렇게 얻어진 환자의 CT 데이터 와 구강 스캐너를 이용한 디지털 스캔 데이터를 이용하 여 디지털 모형분석 및 \#36 치아 부위 임플란트 식립 및 보철 수복을 위한 계획을 시행하였다(Fig. 3). 수술용 가 이드 제작 및 맞춤형 타이타늄 지대주 제작과 함께 임시 보철물을 제작하였다. 수술용 가이드는 Neobiotech의 NeoGuide로 제작하였으며, 제조사의 CAD/CAM 소프 트웨어를 사용하여 디자인 및 제작하였다.

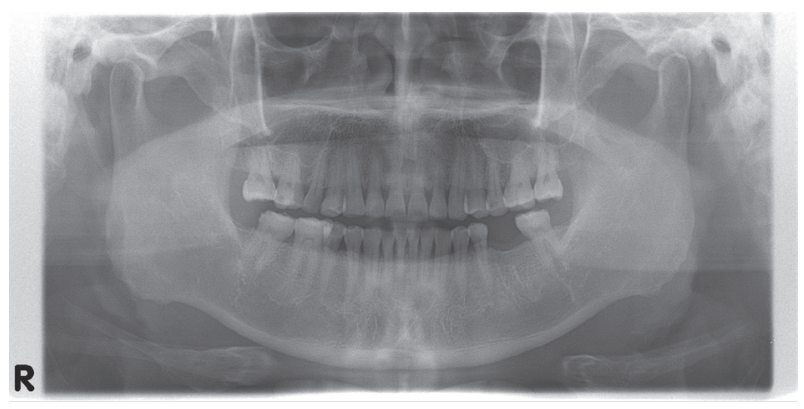

Fig. 1. Initial panorama view.

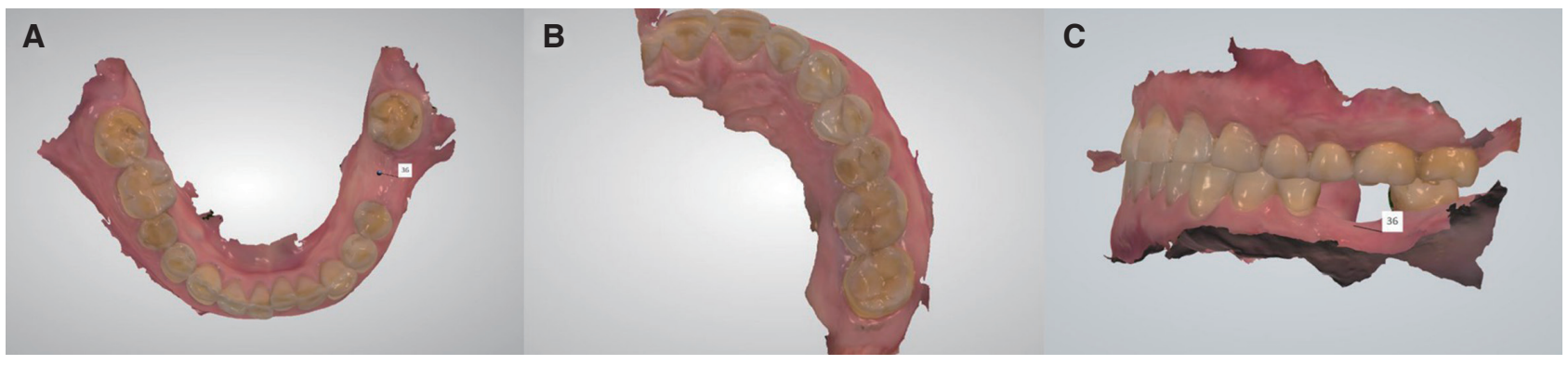

Fig. 2. Initial digital impression taking by intraoral scanner. (A) Screenshot of the digital impression of the mandible, (B) Screenshot of the digital impression of the half arch of maxilla, (C) Screenshot of the digital bite registration. 


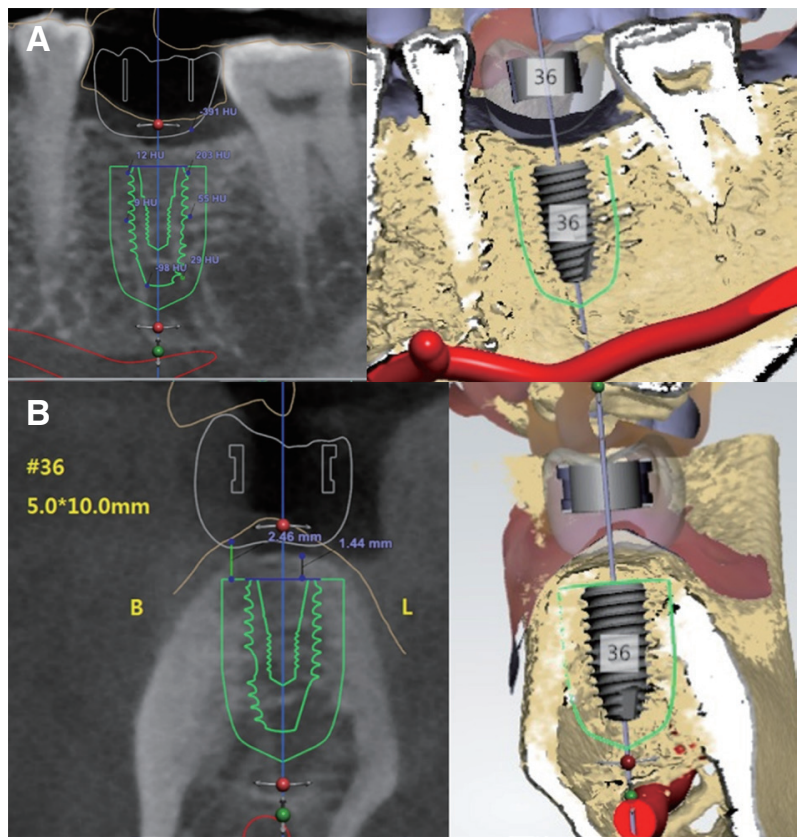

Fig. 3. 3D digital implant planning with software. $(A)$ Frontal view, (B) Axial view.

임플란트 식립 수술을 위해 내원하여 통법에 따른 구 강 및 안면 소독과 국소마취 시행 후 임플란트 식립 제조 사(Neobiotech, Seoul, Korea)의 프로토콜을 준수하여 식 립하였다. 수술 전 제작한 수술용 가이드를 구강 내에 장
착하였다. 적절하게 위치 되었는지, 정확한 위치에 수술용 가이드가 장착되어 계획한 위치로 정확한 임플란트 식립 이 가능한 지 확인하였다. 무절개 수술로 절개 없이 수술 용 가이드만을 이용하여 수술 계획을 하였으나, 부착치은 의 양이 조금 부족하다고 판단하여 최소 절개한 후 식립 하였다. Neobiotech의 즉시부하 식립 방법을 준수하여 드 릴링하고 임플란트를 식립하였다(Fig. 4). 가이드와 함께 토크를 측정하면 부정확 하므로 정해진 식립 깊이로 식립 후 가이드를 제거하고 토크렌치를 이용하여 식립 토크를 측정하였다. 초기 임플란트 안정성 평가를 위해 Osstell Mentor $^{\mathrm{TM}}$ (Osstell, Gothenburg, Sweden)를 이용하여 임 플란트 안정성 지수(implant stability quotient, ISQ) 값 을 측정하였다. ISQ 값은 72 로 만족할 만한 수치로 나타 났으며, 절개한 부위 봉합하여 치유 지대주(healing abutment)를 장착하였다. 임플란트 식립 후 상부 연조직의 두 께를 고려하여 적당한 길이의 치유지대주가 구강 내에 노출되도록 선택하여 장착한 후 방사선사진 촬영하였다 (Fig. 5). 수술 후 처치를 위해 7일간 진통제와 항생제를 복 용하도록 처방하였으며, $0.1 \%$ 클로로헥시딘(chlorhexidine) 용액으로 수술 후 7일간 매일 5회 정도 양치하도록 하였으며, 치유 지대주가 구강 내에 노출되어 있으므로 구강위생에 유의하도록 환자에게 지시하였고 염증 반응, 감염, 동통 등 이상 증상 발현 시 즉시 내원토록 하였다.
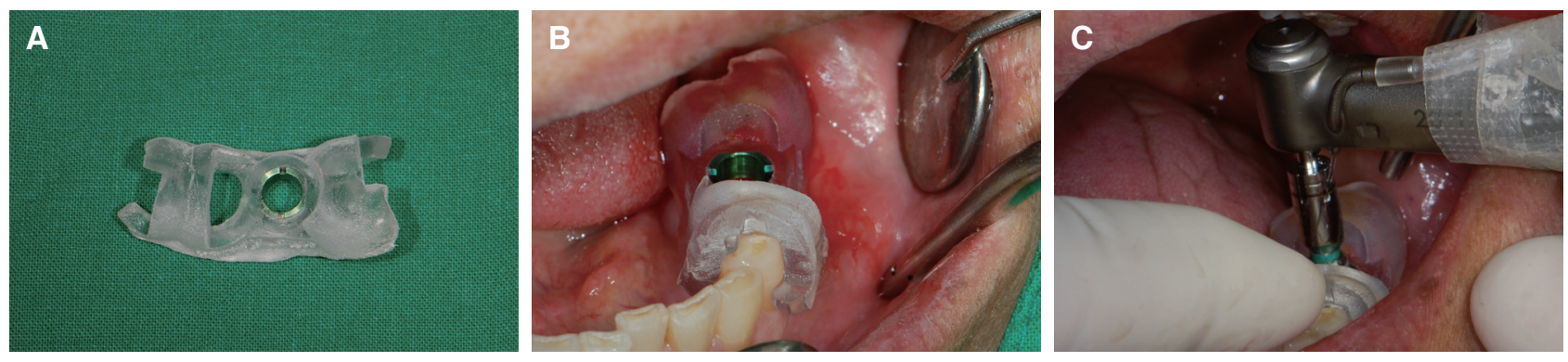

Fig. 4. (A) The surgical guide for the navigated implant placement, (B) Placement of surgical guide, (C) Implant placement using surgical guide.
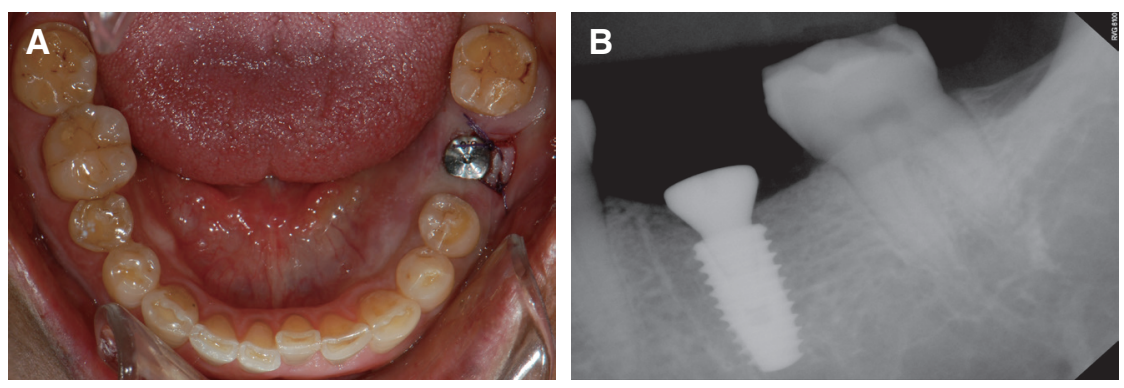

Fig. 5. (A) Healing abutment connection, (B) Periapical view taking after implant placement. 
임플란트 식립 수술 1주일 후 내원하여 봉합사를 제거 하고 ISQ값을 측정하였으며, ISQ 86으로 임플란트의 안 정도 측정 결과를 만족하였으며 연조직 치유도 아직 완 전하지는 않지만 양호하게 치유된 양상을 확인할 수 있 었다. 치유 지대주를 제거한 뒤 미리 나사-시멘트 유지형 보철물(SCRP (screw \& cemented retained prosthesis) type)으로 제작한 타이타늄 맞춤형 지대주와 임시수복물 을 시적하였다. 근원심 접촉면을 조절한 후 구강 내 고정 체에 $25 \mathrm{Ncm}$ 로 타이타늄 맞춤형 지대주 체결하였다. 환 자가 정상적인 교합력으로 물었을 때 Shim-stock (두께 $8 \mu \mathrm{m}) 1$ - 2장이 저항 없이 빠져 나오고, 꽉 물었을 때는 Shim-stock 1장이 저항이 느껴지면서 빠져나가는 정도 로 교합 조정을 시행하였다. 교합력은 고정체 장축에 해 로운 측방력이 가해지지 않도록 조정하였다. 임시수복물 은 임시접착제(Tempbond, Kerr, Orange, USA)를 사용 하여 맞춤형 지대주에 접착하고 수복물 장착 직 후 방사 선 촬영을 하였다(Fig. 6, 7).

수술 후 8 주 후 최종 수복물 제작을 위한 디지털 인상 및 중간 점검을 위한 내원하였다. 유지기간 동안 임플란 트의 동요가 있었는지, 환자가 불편감을 느끼는지, 방사 선 사진상 임플란트 고정체 주위에 방사성 투과상이 나 타나는지, 변연골 흡수가 일어나는지를 관찰하기 위해
방사선사진 촬영하고 임플란트 안정도 측정 하였다. ISQ 값은 89로 나타났으며 합착된 임시수복물을 제거한 뒤 임플란트 고정체에 타이타늄 맞춤형 지대주 상태에서 (Fig. 8) 구강 스캐너를 이용하여 하악 디지털 인상 채득 하였다. 대합되는 좌측 상악 부위도 스캔 한 후 교합 상 태에서 협면 스캔을 통해 교합 채득 시행하였다(Fig. 9). 환자에게 구강위생 교육을 다시 한번 시행하였으며, 임 시 수복물을 재장착 하였다.

최종 지르코니아 수복물은 임시 보철 장착 11 주 후(고 정체 식립 후 12 주 후)에 완성하여, 구강 스캔한 타이타 늄 맞춤형 지대주 상부에 지르코니아 크라운으로 제작 하였다. 최종 보철물 장착 전 ISQ는 90 을 나타내었다. 근 원심 접촉점을 조절한 후 교합 조정을 시행하였다. 교합 력은 고정체 장축에 해로운 측방력이 가해지지 않도록 조정하였다. 구강 내 고정체에 $30 \mathrm{Ncm}$ 로 타이타늄 맞 춤형 지대주 체결하였다. Resin-modified glass ionomer 시멘트를 이용해 접착하였다. 최종 수복물 장착 후 방사 선 사진 촬영 하였다(Fig. 10, 11). 환자에게 임플란트 보 철물의 유지, 관리를 위해 구강 위생 관리에 대해 교육한 후, 정기적인 내원 및 지속적인 관리 필요성에 대해 고지 하였으며, 정기적인 내원 및 예후 관찰을 위해 지속적인 점검 예정이다.
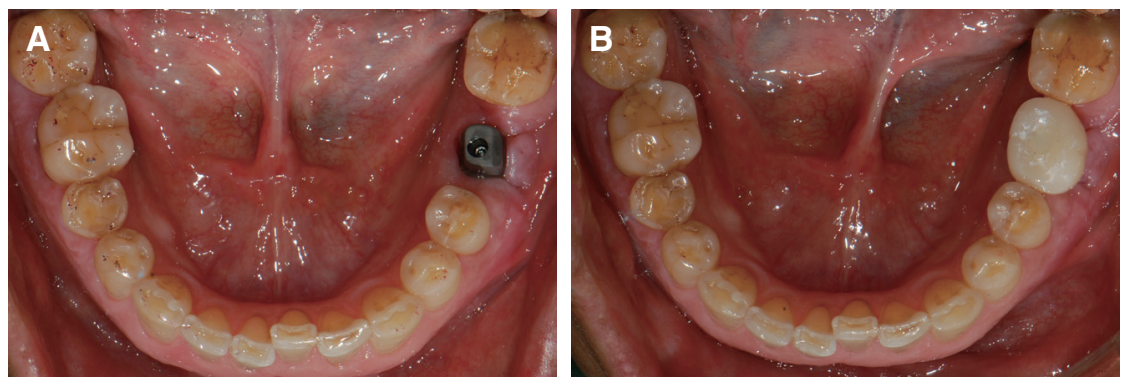

Fig. 6. (A) Ti customized abutment adaptation and (B) Immediate loading with a provisional restoration 1 week later after implant placement.

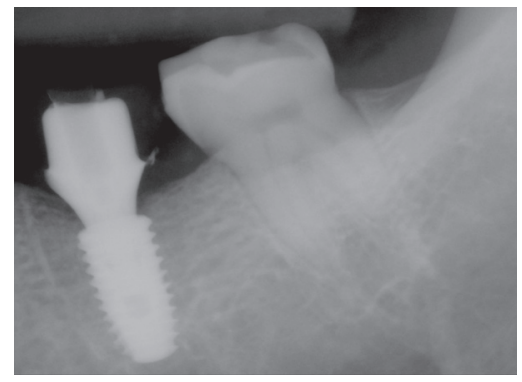

Fig. 7. Periapical view taking 1 week later after implant placement.

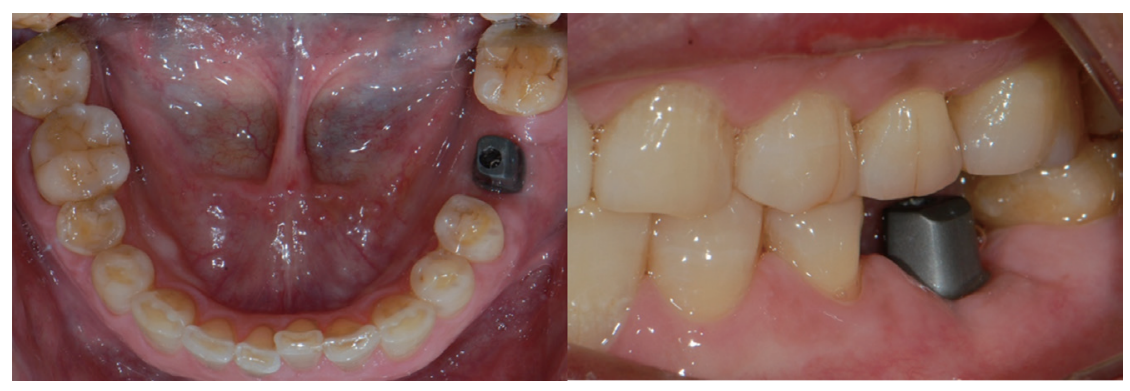

Fig. 8. Preparation abutment level digital impression taking for definitive restoration. 
A

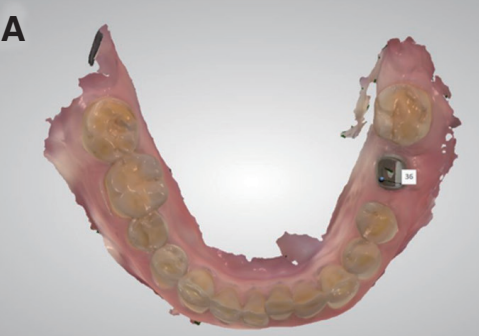

B

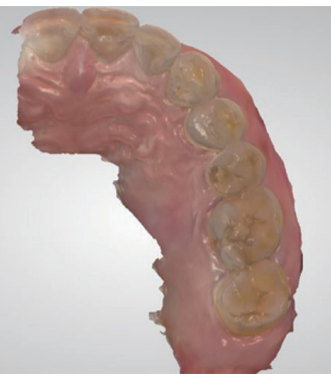

C

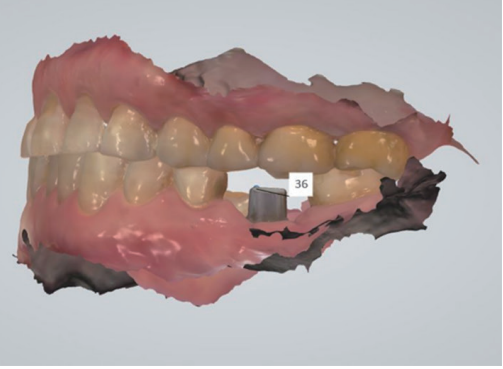

Fig. 9. Digital impression taking for definitive restoration by intraoral scanner. (A) Screenshot of the digital impression of the mandible, (B) Screenshot of the digital impression of the half arch of maxilla, (C) Screenshot of the digital bite registration.

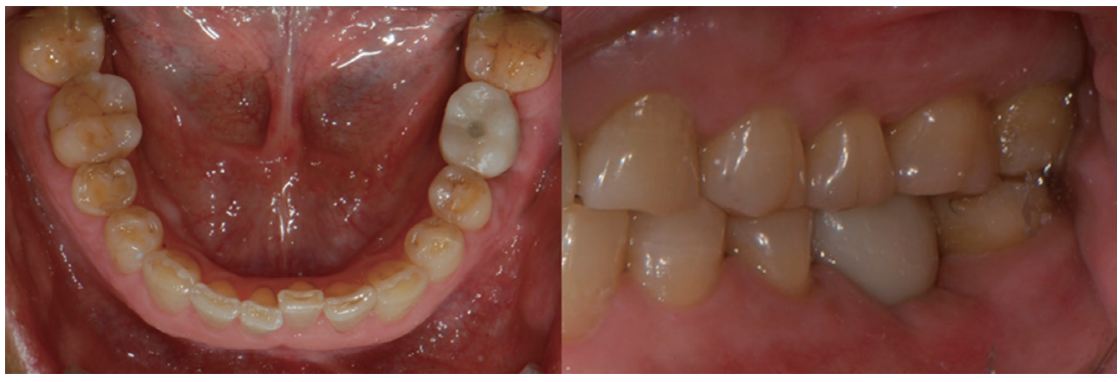

Fig. 10. Final restorations in the mandible with monolithic zirconia restoration.

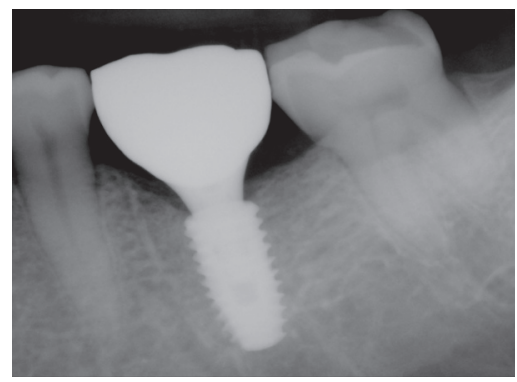

Fig. 11. Periapical view taking 12 weeks later after implant placement.

\section{고찰}

컴퓨터 보조 수술(CAS)은 철적 요인과 해부학적 요인 모두에 대해 최적의 삼차원적 임플란트 위치를 결정할 수 있게 해주며 중요 해부학적 구조물의 침범에 대해 미 리 대비할 수 있어 구체적이고 정확한 치료 계획을 할 수 있었다. CAS를 이용하여 판막을 거상하지 않는 무절개 수술이 가능하긴 하더라도 기본적으로 상악에서 5-6개 월, 하악에서 3 - 4개월의 치유기간이 필요하다. 하지만 이러한 기간은 임상에서 저작, 발음, 심미 등의 상실된 치 아 부위의 기능을 회복하기 까지 꽤나 긴 시간이라고 할 수 있다. 이러한 시간을 단축 시키기 위해 다양한 시도들 이 행해져 왔으며, 조기에 상실된 치아 부위 기능을 회복 하기 위한 노력들이 있어 왔다. 즉시 부하의 개념이 등장 하였으며, 이런 술식은 환자의 불편감도 줄일 수 있을 뿐 만 아니라, 초기 고정력이 우수한 임플란트에서 즉시하 중 시 지연하중과 유사한 성공률을 나타낸다고 보고된 바 있다..$^{7-9}$ 이런 즉시 부하에서 임시 지대주를 사용할 수 도 있으나, 최종 보철물을 위한 지대주를 즉시 부하에 사 용할 수도 있으며, 본 증례에서 이와 같이 임시 지대주 사
용 대신, 최종 보철물을 위한 타이타늄 맞춤형 지대주를 수술 전 미리 제작하여 수술 후 장착하였다. 이러한 CAS 및 임플란트 식립 후 즉시 부하를 위해서는 무엇보다도 적절한 위치에 임플란트 식립을 계획하고, 계획한 위치에 임플란트를 정확하게 식립하는 것이 중요하다. 최종 목 표에 부합하는 보철물의 위치를 설정하고, 보철물의 위 치를 고려하여 임플란트 식립 위치를 계획하는 데에는 해부학적 구조물의 위치나 잔존골, 실제 수술을 하는 상 황에 있어서는 환자의 움직임과 시야 확보의 어려움도 고려해야 한다. 이를 위해 여러가지 방법들이 제안되어 왔으며, 수술 시 이상적인 위치에 시술을 할 수 있도록 유 도(guided)하는 시스템도 그런 방법 중 하나라고 할 수 있다. 이 방법을 이용하여 수술용 가이드를 본 증례에 사 용하여 임플란트 식립에 활용하였으며, 수술 시간 단축 및 계획한 위치로 식립되어 미리 제작한 즉시 부하 보철 물을 약간의 조정만으로 바로 장착할 수 있어 전체적인 치료결과가 양호하였다.

본 증례에서 임플란트 수술 직후, 1 주일 후, 8 주 후, 12 주 후 각각 $\mathrm{ISQ}$ 측정을 시행하였는데, Calandiello 등 ${ }^{10}$ 은 즉시하중 임플란트의 평균 초기 ISQ가 76 , 최소 수치 
는 58이었다고 보고하였으며, 2003년 Glause 등 ${ }^{11}$ 은 초 기 ISQ 71이었다고 보고한 바 있다. 본 증례에서 측정한 ISQ수치도 이에 부합하였으며, 즉시 하중 이후에도 안정 적인 수치가 나타난 것을 확인 하였다. 치료기간 단축 및 연조직의 심미성 면에서 유리하였으나, Yong과 $\mathrm{Moy}^{12}$ 는 즉시 하중의 조기 발생 가능한 합병증으로 임플란트의 실패, 보철물 나사 풀림, 발음 문제 등이 나타날 수 있으 며, 후기 합병증으로 임플란트 주변 연조직 결손으로 인 한 보철물 하방 공간 발생, 나사 풀림, 나사 파절, 환자의 심미적 불만족 등이 나타날 수 있다고 보고한 바 있다. ${ }^{13}$ 본 증례에서도 이러한 조기, 후기 합병증이 발생 가능성 을 간과하지 않고 지속적인 관찰 및 점검을 통해 예방해 야 하겠다.

이와 같은 임플란트 가이드 수술을 위한 시스템의 발 전은 여러가지 학문과 기술의 발전에 기인하는데 CBCT 같은 방사선 촬영 기기와 기술의 발달 및 컴퓨터 성능의 개선과 $3 \mathrm{D}$ 프린팅 기술의 발전에 의한 것이라 할 수 있 다. 본 증례에서 이용한 방식은 이러한 최신 방법을 통하 여 전통적인 인상재를 이용한 인상채득 과정없이 임플란 트 식립에서 보철 수복까지 완료 하였다. 임플란트 식립 위치는 식립 깊이, 각도의 오차, 측방 변위 등의 오차가 발생할 수 있으며 ${ }^{14,15}$ 이러한 오차를 보상하기 위하여, 임 시 수복물 장착 및 지르코니아 최종 수복물 장착 시 약간 의 인접면 접촉 및 교합 조정이 필요하였다. 단일 구치부 임플란트 부위이며, 수술 시 시야 확보, 환자의 협조도, 수술용 가이드의 정확성 등에 의해 비교적 계획한 위치 에 성공적으로 식립 되어 보철물의 적합도도 향상되었다 고 볼 수 있다.

\section{결론}

완전한 디지털 workflow를 통한 가이드 수술 및 디지 털 보철 수복과정은 식립과 제작과정, 보철 수복에서의 오차를 수정하기 위한 약간의 조정 및 수정 과정이 필요 하다. 다수 치아 상실 및 복잡한 치료 계획을 요하는 환 자에서 적용하기에는 고려해야 할 사항이 많으며 아직 완전히 도입하기에는 다소 무리가 있을 수 있다. 디지털 인상 채득을 이용하여 수술 전 맞춤형 지대주 및 임시수 복물 제작을 통하여 단일 치아 임플란트 지지형 보철물 을 즉시 부하를 통해 수복한 본 증례에서는 성공적인 수 복이 가능하였으며, 환자의 만족도 및 정확성 면에서 만 족할 만한 결과를 나타내었으나 향후 지속적인 관찰 및
관리가 필요하다. 완전한 디지털 보철물 제작을 위한 임 상적인 프로토콜 마련을 위해 좀 더 다양한 증례와 다수 치아 상실 증례에서도 임상적으로 유용할 것인지 추가적 인 연구가 필요할 것으로 사료된다.

\section{Acknowledgements}

본 연구는 보건복지부의 재원으로 보건의료연구개발 사업의 지원에 의하여 이루어진 것임(H16C1173).

\section{ORCID}

Hyun-jeong Lim https://orcid.org/0000-0001-8637-1993

Myung-Joo Kim https://orcid.org/0000-0003-2020-5284

Ho-Beom Kwon https://orcid.org/0000-0003-4973-7727

Young-Jun Lim https://orcid.org/0000-0003-2504-9671

\section{References}

1. Pjetursson BE, Brägger U, Lang NP, Zwahlen M. Comparison of survival and complication rates of tooth-supported fixed dental prostheses (FDPs) and implant-supported FDPs and single crowns (SCs). Clin Oral Implants Res 2007;18:97-113.

2. Tahmaseb A, Wismeijer D, Coucke W, Derksen W. Computer technology applications in surgical implant dentistry: a systematic review. Int J Oral Maxillofac Implants 2014;29:25-42.

3. Azari A, Nikzad S. Computer-assisted implantology: historical background and potential outcomes - a review. Int J Med Robot 2008;4:95-104.

4. Widmann G, Bale RJ. Accuracy in computer-aided implant surgery - a review. Int J Oral Maxillofac Implants 2006;21:305-13.

5. Jung RE, Schneider D, Ganeles J, Wismeijer D, Zwahlen M, Hämmerle CH, Tahmaseb A. Computer technology applications in surgical implant dentistry: a systematic review. Int J Oral Maxillofac Implants 2009;24:92-109.

6. Fortin T, Bosson JL, Isidori M, Blanchet E. Effect of flapless surgery on pain experienced in implant placement using an image-guided system. Int J Oral Maxillofac Implants 2006;21:298-304.

7. Aalam AA, Nowzari H, Krivitsky A. Functional 
restoration of implants on the day of surgical placement in the fully edentulous mandible: a case series. Clin Implant Dent Relat Res 2005;7:10-6.

8. Wolfinger GJ, Balshi TJ, Rangert B. Immediate functional loading of Brånemark system implants in edentulous mandibles: clinical report of the results of developmental and simplified protocols. Int J Oral Maxillofac Implants 2003;18:250-7.

9. Ioannidou E, Doufexi A. Does loading time affect implant survival? A meta-analysis of 1,266 implants. J Periodontol 2005;76:1252-8.

10. Calandriello R, Tomatis M, Rangert B. Immediate functional loading of Brånemark system implants with enhanced initial stability: a prospective 1- to 2 -year clinical and radiographic study. Clin Implant Dent Relat Res 2003;5:10-20.

11. Glauser R, Lundgren AK, Gottlow J, Sennerby L, Portmann M, Ruhstaller P, Hämmerle CH. Immediate occlusal loading of Brånemark TiUnite implants placed predominantly in soft bone: 1 -year results of a prospective clinical study. Clin Implant Dent Relat Res 2003;5:47-56.

12. Yong LT, Moy PK. Complications of computeraided-design/computer-aided-machining-guided (Nobel Guide) surgical implant placement: an evaluation of early clinical results. Clin Implant Dent Relat Res 2008;10:123-7.

13. Komiyama A, Klinge B, Hultin M. Treatment outcome of immediately loaded implants installed in edentulous jaws following computer-assisted virtual treatment planning and flapless surgery. Clin Oral Implants Res 2008;19:677-85.

14. Dreiseidler T, Neugebauer J, Ritter L, Lingohr T, Rothamel D, Mischkowski RA, Zöller JE. Accuracy of a newly developed integrated system for dental implant planning. Clin Oral Implants Res 2009;20:1191-9.

15. Eggers G, Patellis E, Mühling J. Accuracy of template-based dental implant placement. Int J Oral Maxillofac Implants 2009;24:447-54. 


\section{수술용 가이드와 modeless 디지털 보철물을 이용한 하악 구치부 단일 임플란트 즉시 하중 증례}

\section{임현정, 김명주, 권호범, 임영준*}

서울대학교 치과대학 치과보철학교실

본 증례는 완전한 디지털 workflow로 단일 치아 임플란트 지지형 보철물을 즉시 부하하여 수복한 증례이다. 하악 제1대 구치 상실로 내원한 환자로, 구강 스캐너로 구내 디지털 인상채득 후, CT데이터와 디지털 스캔 데이터를 통해 제작한 수 술용 가이드를 이용하여 임플란트를 식립하였다. 술 후 1주일 후, 맞춤형 지대주와 임시치아를 체결하여 즉시부하 하였 다. 술 후 8 주 후 지대주 레벨에서 구강스캐너를 이용하여 디지털 인상채득 후, 술 후 3개월에 지르코니아 최종 보철물을 장착하였다. 본 증례는 환자의 만족도 및 정확성 면에서 만족할 만한 결과를 나타내었으며, 완전한 디지털 과정을 통한 수복 결과 정확성, 심미성, 기능성 면에서 만족할 만한 결과를 나타내었기에 보고하는 바이다.

(구강회복응용과학지 2017;33(4):299-306)

주요어: 디지털 인상; 수술용 가이드; $\mathrm{CAD} / \mathrm{CAM}$; 즉시 부하; 구강 스캐너

*교신저자: 임영준

(03080)서울시 종로구 대학로 101 서울대학교 치과대학 치과보철학교실

Tel: 02-2072-3816 | Fax: 02-2072-3860 | E-mail: limdds@snu.ac. kr

접수일: 2017년 9월 5일 | 수정일: 2017년 9월 20일 | 채택일: 2017년 9월 21일 